\title{
Interaction between insulin receptors and major histocompatibility complex antigens in mouse liver membranes
}

\author{
N. Brossette, E. Van Obberghen and M. Fehlmann \\ INSERM U 145, Faculté de Médecine, Nice, France
}

\begin{abstract}
Summary. Insulin receptors from $\mathbf{H}-2^{\mathbf{k}}$ mouse liver membranes were specifically labelled using a photoreactive insulin analogue coupled to the $\alpha$-subunit $\left(\mathrm{M}_{\mathrm{r}} 130,000\right)$ of the receptor by ultraviolet-irradiation. Up to $25 \%$ of the labelled insulin receptors recovered after membrane solubilization and precipitable by anti-insulin receptor antibodies could be immunoprecipitated by various monoclonal antibodies reacting with $\mathrm{H}-2 \mathrm{~K}^{\mathrm{k}}$ antigens. None of these monoclonal antibodies inhibited insulin binding to its receptor. These results show
\end{abstract}

that insulin receptors and $\mathrm{H}-2 \mathrm{~K}^{\mathrm{k}}$ antigens interact in liver plasma membranes to form non-covalent complexes. This association between insulin receptors and major histocompatibility complex antigens could be involved in the pathogenesis of certain forms of insulin resistance.

Key words: Insulin receptors, histocompatibility complex antigens, immunoprecipitation, monoclonal antibodies.
The major histocompatibility complex (MHC) of the mouse encodes a variety of transmembrane glycoproteins involved in the immune response $[1,2] . \mathrm{H}-2 \mathrm{~K}, \mathrm{H}$ $2 \mathrm{D}$ and $\mathrm{H}-2 \mathrm{~L}$ are the three murine MHC antigens, referred to as the class I antigens, that are recognized together with viral antigens by cytolytic lymphocytes during T-cell mediated cytolysis of infected cells. However, the idea is now emerging that MHC antigens may function in a wider context than solely that of immune regulation [3]. Indeed, we have recently reported that insulin receptors from mouse liver membranes can be immunoprecipitated by antibodies reacting with class I MHC antigens [4]. By using different monoclonal antibodies of known specificities, we have now investigated whether insulin receptors are precipitated by anti-H-2 antibodies due to a structural homology between insulin receptors and $\mathrm{H}-2$ antigens, or to some physical interaction between these two membrane components.

\section{Materials and methods}

\section{Materials}

The photoreactive insulin analogue B2(2-nitro-4-azidophenylacetyl)des-Phe ${ }^{\mathrm{B} 1}$ insulin was prepared by D. Saunders and D. Brandenburg, Wollforschungsinstitut, Aachen, FRG. Native porcine insulin and photoreactive insulin were iodinated to a specific activity of $200-250 \mathrm{Ci} / \mathrm{g}$ by using the chloramine-T method [4]. Serum from pat- ient B9 with autoantibodies to the insulin receptor was kindly given by C.R.Kahn, Joslin Research Laboratory, Boston, Massachusetts, USA [5]. Antibodies reacting with $\mathrm{H}-2^{\mathrm{k}}$ antigens are listed in Table 1, and are described by their target molecule specificity and their correspondence to known serological specificities. All antibodies are monoclonal IgG2a, $\kappa$ mouse antibodies, except for $\mathrm{H}-100-30 / 23$ which is an IgG2b monoclonal antibody. The reagents for sodium dodecyl sulphate-polyacrylamide gel electrophoresis (SDS-PAGE) were purchased from Bio-Rad, Richmond, California, USA.

\section{Photolabelling of insulin receptors}

Liver membranes were purified from $\mathrm{C} 3 \mathrm{H}\left(\mathrm{H}-2^{k}\right)$ mice as described by Neville [9]. Insulin receptors were labelled using a photoreactive insulin method [10]. Briefly, liver membranes $(0.5 \mathrm{mg}$ protein) were incubated in $0.2 \mathrm{ml}$ of Krebs-Ringer bicarbonate buffer containing $1 \%$ bovine serum albumin, bacitracin $(0.8 \mathrm{mg} / \mathrm{ml})$, phenyl methyl sulphonyl fluoride $(2 \mathrm{mmol} / 1)$, aprotinin $(10,000$ trypsin inhibitor units $/ \mathrm{ml})$ and $30 \times 10^{6} \mathrm{cpm}$ of ${ }^{125} \mathrm{I}$-photoreactive insulin for $3 \mathrm{~h}$ at $15^{\circ} \mathrm{C}$ in the dark. Photoactivation was induced by a 5-min exposure of the liver membrane suspension to ultraviolet light given by a water-cooled high pressure mercury lamp (Philips HPK $125 \mathrm{~W}$ Eindhoven, The Netherlands) and filtered through a black glass filter (UVW 55, Hanau, FRG).

\section{Solubilization of liver membranes and immunoprecipitation}

Following ultraviolet-irradiation membranes were collected by centrifugation $(18,000 \mathrm{~g}$ for $5 \mathrm{~min}$ ) and resuspended in $0.1 \mathrm{ml}$ of buffer containing Hepes $(50 \mathrm{mmol} / 1$; $\mathrm{pH} 7.4), \mathrm{NaCl}(150 \mathrm{mmol} / 1)$, bacitracin, aprotinin, phenylmethyl sulphonyl fluoride at the concentration 


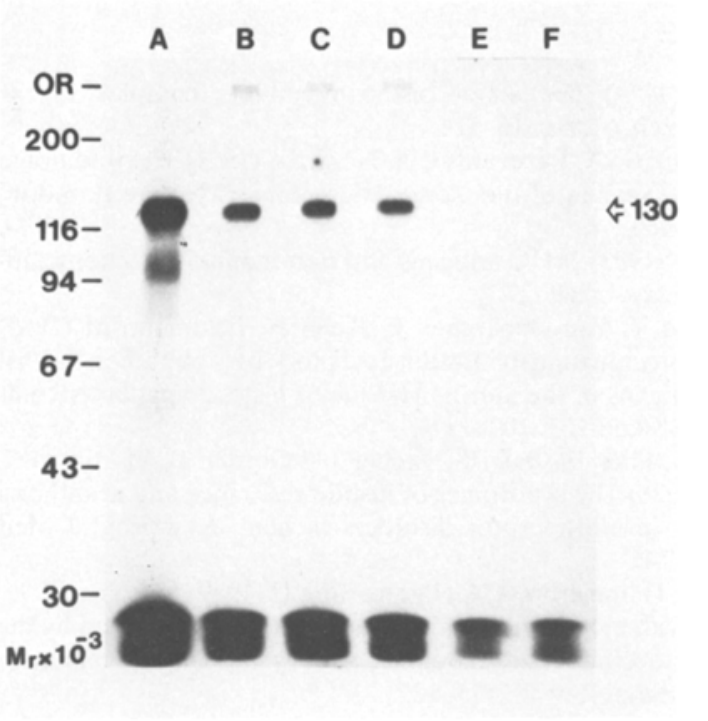

Fig. 1. Immunoprecipitation of photolabelled $M_{r} 130,000$ insulin re ceptor subunit. Insulin receptors from $\mathrm{H}-2^{\mathrm{k}}$ mouse liver membranes were labelled with ${ }^{125}$-photoreactive insulin and solubilized in $1 \%$ Nonidet-40. Thereafter, immunoprecipitation with the following antibodies was performed: (A) serum containing antibodies to insulin receptor at a 1:300 dilution; (B) monoclonal antibodies reacting with $\mathrm{K}^{\mathrm{k}}, \mathrm{D}^{\mathrm{k}}(\mathrm{H}-100-30 / 23)$; (C and $\left.\mathrm{D}\right)$ monoclonal antibodies reacting with $\mathrm{K}^{\mathrm{k}}$ (H-100-5/28 and 11-4-1, respectively). (B, C and D were used at $20 \mu \mathrm{g} / \mathrm{ml} ; \mathrm{E}, 20 \mu \mathrm{g} / \mathrm{ml}$ mouse $\mathrm{IgG} ; \mathrm{F}$, normal human serum at a $1: 300$ dilution. $\mathrm{OR}=$ origin.

Table 1. Immunoprecipitation of insulin receptors and inhibition of insulin binding by anti-insulin receptor antibodies and anti-H- ${ }^{k}$ monoclonal antiboclies

\begin{tabular}{|c|c|c|c|c|c|}
\hline Antibody & $\begin{array}{l}\text { Refer- } \\
\text { ence }\end{array}$ & $\begin{array}{l}\text { Reactive } \\
\text { antigen }\end{array}$ & $\begin{array}{l}\text { Corre- } \\
\text { spondence } \\
\text { to known } \\
\text { serological } \\
\text { specifici- } \\
\text { ties }\end{array}$ & $\begin{array}{l}\text { Immuno- } \\
\text { precipi- } \\
\text { tation } \\
\text { (cpm) }\end{array}$ & $\begin{array}{l}\text { Insulin } \\
\text { binding } \\
\text { (cpm } / 80 \mu \mathrm{g} \\
\text { protein) }\end{array}$ \\
\hline Mouse IgG & & - & - & 4782 & $1325 \pm 62$ \\
\hline B-9 & 5 & $\begin{array}{l}\text { Insulin } \\
\text { receptors }\end{array}$ & - & 56385 & $672 \pm 41$ \\
\hline $\mathrm{H}-100-30 / 23$ & 6 & $\mathrm{~K}^{\mathrm{k}}, \mathrm{D}^{\mathrm{k}}$ & $\mathrm{H}-2.5$ & 10186 & $1235 \pm 42$ \\
\hline $3-83$ & 7 & $\mathrm{~K}^{\mathrm{k}}, \mathrm{D}^{\mathrm{k}}$ & $\mathrm{H}-2.5$ & 8895 & $1250 \pm 23$ \\
\hline H-100-5/28 & 6 & $\mathrm{~K}^{\mathrm{k}}$ & $\mathrm{H}-2.11$ & 21406 & $1169 \pm 43$ \\
\hline $11-4-1$ & 8 & $\mathrm{~K}^{\mathrm{k}}$ & $\mathrm{H}-2.11$ & 8815 & $1156 \pm 25$ \\
\hline $16-3-1$ & 7 & $\mathrm{~K}^{\mathrm{k}}$ & $\begin{array}{l}\text { Unidenti- } \\
\text { fied }\end{array}$ & 13962 & $1242 \pm 58$ \\
\hline $15-5-5$ & 7 & $\mathrm{D}^{\mathrm{k}}$ & $\begin{array}{l}\text { Unidenti- } \\
\text { fied }\end{array}$ & 5497 & $1450 \pm 38$ \\
\hline
\end{tabular}

Immunoprecipitations were carried out as described in Material and Methods, with B-9 at a dilution of 1:300 and monoclonal antibodies or mouse IgG at $5 \mu \mathrm{g} / \mathrm{ml}$. Values represent the results of a single representative experiment. Specific insulin binding was measured under the same conditions as those described for photoreactive insulin binding using $10000 \mathrm{cpm}$ of ${ }^{125} \mathrm{I}$-insulin per assay. Values represent mean \pm SEM of four separate determinations. Non-specific binding, measured in the presence of $1 \mu \mathrm{mol} / 1$ unlabelled insulin, ranged between 55 and $119 \mathrm{cpm}$ indicated above, and 1\% Nonidet P40. Membranes were solubilized for $90 \mathrm{~min}$ at $4^{\circ} \mathrm{C}$ by continuous stirring. This preparation was centrifuged at $150,000 \mathrm{~g}$ for $15 \mathrm{~min}$ at $4^{\circ} \mathrm{C}$ (Airfuge, Beckman, Fullerton, California, USA) and the supernatant was incubated for $16 \mathrm{~h}$ at $4^{\circ} \mathrm{C}$ with different antibodies. Immunoprecipitation with protein $\mathrm{A}$ was achieved by addition of $S$. aureus cells (Pansorbin). After $4 \mathrm{~h}$ at $4^{\circ} \mathrm{C}$ the immunoprecipitates were collected by centrifugation $(18,000 \mathrm{~g}$ for $1 \mathrm{~min}$ at $4^{\circ} \mathrm{C}$ ) and washed twice with $50 \mathrm{mmol} / 1 \mathrm{Hepes} / 150 \mathrm{mmol} / 1$ $\mathrm{NaCl}$.

\section{Gel electrophoresis and autoradiography}

The immunoprecipitates were boiled for $5 \mathrm{~min}$ in a solution containing $3 \%(\mathrm{w} / \mathrm{v}) \mathrm{SDS}, 10 \%(\mathrm{v} / \mathrm{v})$ glycerol, $10 \mathrm{mmol} / 1$ sodium phosphate, $2 \%(\mathrm{v} / \mathrm{v}) 2$-mercaptoethanol, and $0.01 \%$ bromophenol blue. Aliquots of the precipitates were analyzed by one-dimensional SDS-PAGE [11], with a $7.5 \%$ acrylamide gel as resolving gel. The $\mathrm{M}_{\mathrm{r}}$ of the standards used were: myosin, 200,$000 ; \beta$-galactosidase; 116,000 ; phosphorylase b, 94,000 ; bovine serum albumin, 67,000 ; ovalbumin, 43,000 ; carbonic anhydrase, 30,000 ; soybean trypsin inhibitor, 20,000; and lysozyme, 14,400. The gels were stained, dried, and autoradiographed by exposing the gels to Kodak-X-Omat film.

\section{Results}

${ }^{125}$ I-Photoreactive insulin analogues have been shown to label exclusively the $\alpha$-subunit $\left(\mathrm{M}_{\mathrm{r}} 130,000\right)$ of the insulin receptor in a variety of tissues and cell types [7]. When photolabelled $\mathrm{H}-2^{\mathrm{k}}$ mouse liver plasma membranes were solubilized in $1 \%$ Nonidet-P40, the radioactive insulin-receptor complexes could be immunoprecipitated by anti-insulin receptor antibodies (Fig.1, lane A). The amount of labelled insulin receptors that was extracted by detergent and immunoprecipitated with anti-insulin receptor antibodies represented approximately $70 \%$ of all the labelled plasma membrane receptors [4]. This fraction will be designated hereafter as the recoverable insulin receptors. Up to $25 \%$ of these recoverable insulin receptors were immunoprecipitated by monoclonal antibodies reacting with class I antigens of the $\mathrm{H}-2^{\mathrm{k}}$ haplotype (Fig. 1, lanes B-D). No immunoprecipitation could be detected with control mouse IgG or normal human serum (Fig. 1, lanes E and F).

To analyse further the nature of the antibodies that are able to immunoprecipitate insulin receptors, we have tested various hybridoma supernatants that contain monoclonal antibodies reacting with different antigens of the $\mathrm{H}-2^{\mathrm{k}}$ complex, some of them corresponding to known serological specificities. Table 1 shows that all the monoclonal antibodies reacting with $\mathrm{K}^{\mathrm{k}}$ precipitated substantial amounts of the recoverable insulin receptors. By contrast, antibodies reacting only with $\mathrm{D}^{\mathrm{k}}$ precipitated the same amount of radioactivity as did normal mouse IgG. When analyzed on SDS-gels, this corresponded to a negligible amount of labelled $\alpha$ subunits (not shown).

None of the monoclonal antibodies used inhibited the binding of insulin to its receptor, contrasting with anti-insulin receptor antibodies that decreased specific insulin binding by $50 \%$ (Table 1 ). 


\section{Discussion}

Immunoprecipitation of insulin receptors by anti-H-2 monoclonal antibodies could result either from the recognition by the antibodies of epitopes common to $\mathrm{H}-2$ antigens and insulin receptors (cross-reactivity), or from physical interaction between insulin receptors and $\mathrm{H}-2$ antigens, the antibody recognizing only the latter (coprecipitation). The observation that several antibodies reacting with different antigenic determinants on $\mathrm{H}-2 \mathrm{~K}^{\mathrm{k}}$ antigens are all able to precipitate the insulin receptor, strongly supports the co-precipitation hypothesis. Moreover, antibodies that precipitate insulin receptors in $\mathrm{H}-2^{\mathrm{k}}$ mouse liver membranes are unable to do so in $\mathrm{H}-2^{\mathrm{b}}$ mouse membranes, indicating the necessary presence of the corresponding $\mathrm{H}-2$ antigen (results not shown). This argues again in favour of an interaction between MHC class I antigens and insulin receptors.

There is an increasing body of evidence that $\mathrm{MHC}$ antigens interact with other cellular components at the cell surface. Several studies have indicated that some virus antigens and $\mathrm{H}-2$ antigens can be co-precipitated by appropriate antibodies [12-14], suggesting that the MHC-restricted recognition of viral-infected cells by cytolytic T-lymphocytes involves an interaction between these two entities. The extensive genetic polymorphism of class I antigens, as well as their structural and genetic similarity with immunoglobulins suggest that MHC antigens may function as primitive cell surface antibodies [15]. One would thus expect that MHC antigens can also interact with cell-surface proteins outside the immune system. Such interactions have been reported between H-2-K and H-2-D antigens and actin [16]. Moreover, glucagon binding and glucagon-stimulated adenylate cyclase activity vary in different mouse strains and these effects were found to map at the $\mathrm{K}$ and $\mathrm{D}$-ends of the MHC [17]. Finally, a functional interaction has been found between class I antigens and the binding of epidermal growth factor and insulin to their respective receptors in cultured human cells [3].

These observations together with our present results suggest a possible role of $\mathrm{MHC}$ antigens as a structural part of a large number of receptors with different biological functions [18]. This would constitute a physical basis for the concept of receptor transmodulation where the affinity and the number of a hormone receptor expressed at the cell surface could be regulated through its association with other membrane proteins. In the context of the tyrosine-kinase activity associated with insulin and epidermal growth factor receptors it is particularly intriguing that HLA-A and -B antigens, the equivalent class I antigens in the human system, can be phosphorylated at tyrosine residues [19]. Whether the structural association between class I antigens of the $\mathrm{MHC}$ and insulin receptors, bears a functional implication in the mechanism of insulin action represents a challenging question.

Acknowledgements. We thank Dr. A.M.Schmitt-Verhulst for helpful discussions, G. Visciano for illustration work and J. Duch for excellent secretarial assistance.

\section{References}

1. Klein J (1979) The major histocompatibility complex of the mouse. Science 203: 516-521

2. Klein J, Juretic A, Baxevanis CN, Nagy ZA (1981) The traditional and a new version of the mouse $\mathrm{H}-2$ complex. Nature (London) 291: $455-460$

3. Edidin M (1983) MHC antigens and non-immune functions. Immunol Today 4: 269-270

4. Chvatchko Y, Van Obberghen E, Kiger N, Fehlmann M (1983) Immunoprecipitation of insulin receptors by antibodies against class I antigens of the murine $\mathrm{H}-2$ major histocompatibility complex. FEBS Lett 163: 207-211

5. Kahn CR, Flier JS, Bar RS, Archer JA, Gorden P, Martin MM, Roth $\mathbf{J}$ (1976) The syndromes of insulin resistance and acanthosis nigricans: insulin-receptor disorders in man. New Engl J Med 294: 739-745

6. Lemke H, Hämmerling GJ, Hämmerling U (1979) Fine specificity analysis with monoclonal antibodies of antigens controlled by the major histocompatibility complex and by the Qa/TL region in mice. Immunol Rev 47: 175-182

7. Ozato K, Mayer N, Sachs DH (1980) Hybridoma cell lines secreting monoclonal antibodies to mouse $\mathrm{H}-2$ and Ia antigens. J Immunol 124: $533-540$

8. Oi VT, Jones PP, Goding JW, Herzenberg LA (1978) Properties of monoclonal antibodies to mouse $\mathrm{Ig}$ allotyes, $\mathrm{H}-2$, and $\mathrm{Ia}$ antigens. Curr Top Microbiol Immunol 81: 115-121

9. Neville DM (1968) Isolation of an organ specific protein antigen from cell surface membrane of rat liver. Biochim Biophys Acta 154: $540-552$

10. Fehlmann M, Le Marchand-Brustel Y, Van Obberghen E, Brandenburg D, Freychet P (1982) Photoaffinity labelling of the insulin receptor in intact rat hepatocytes, mouse soleus muscles and cultured human lymphocytes. Diabetologia $23: 440-444$

11. Laemmli UK (1970) Cleavage of structural proteins during the assembly of the head of bacteriophage $\mathrm{T}_{4}$. Nature 227: 680-685

12. Kvist S, Ostberg L, Persson H, Philipson L, Peterson PA (1978) Molecular association between transplantation antigens and cell surface antigen in an adenovirus-transformed cell line. Proc Natl Acad Sci USA 75: 5674-5678

13. Kämpe $O$, Bellgrau D, Hammerling U, Lind P, Pääbo S, Severinsson L, Peterson PA (1983) Complex formation of class I transplantation antigens and a viral glycoprotein. J Biol Chem 258: 10594-10598

14. Signäs C, Katze MG, Persson H, Philipson L (1982) An adenovirus glycoprotein binds heavy chains of class I transplantation antigens from man and mouse. Nature (London) 299: 175-178

15. Cushley W, Owen MJ (1983) Structural and genetic similarities between immunoglobulins and class I histocompatibility antigens. Immunol Today 4: 88-92

16. Koch GLE, Smith MJ (1978) An association between actin and the major histocompatibility antigen H-2. Nature (London) 273: 274-278

17. Lafuse W, Edidin M (1980) Influence of the mouse major histocompatibility complex, $\mathrm{H}-2$, on liver adenylate cyclase activity and on glucagon binding to liver cell membranes. Biochemistry $19: 49-54$

18. Simonsen M, Olsson L (1983) Possible roles of compound membrane receptors in the immune system. Ann Immunol (Paris) 134 D: $85-92$

19. Guild BC, Erikson RL, Strominger JL (1983) HLA-A2 and HLA$\mathrm{B} 7$ antigens are phosphorylated in vitro by Rous sarcoma virus kinase $\left(\mathrm{pp} 60^{\mathrm{v}-\mathrm{sr}}\right)$ at a tyrosine residue encoded in a highly conserved exon of the intracellular domain. Proc Natl Acad Sci USA $80: 2894-2898$

Dr. M.Fehlmann

INSERM U 145

Faculté de Médecine

Chemin de Vallombrose

F-06034 Nice Cedex

France 